\title{
Heritabilitas dan Hubungan Antar Karakter Kuantitatif Kecipir (Psophocarpus tetragonolobus (L.) DC) pada Tiga Lingkungan
}

\author{
Heritability and Relationship Among Traits of Winged Bean \\ (Psophocarpus tetragonolobus (L.) DC) in Three Environments
}

\author{
Dian Rakhmad ${ }^{1}$, Muhamad Syukur ${ }^{2 *}$, dan Willy Bayuardi Suwarno ${ }^{2}$ \\ 'Program Studi Pemuliaan dan Bioteknologi Tanaman, Sekolah Pascasarjana, Institut Pertanian Bogor \\ ${ }^{2}$ Departemen Agronomi dan Hortikultura, Fakultas Pertanian, Institut Pertanian Bogor \\ (IPB University), Jl. Meranti, Kampus IPB Darmaga, Bogor 16680, Indonesia
}

Diterima 28 Oktober 2020/Disetujui 10 Februari 2021

\begin{abstract}
Winged bean (Psophocarpus tetragonolobus (L.) DC) is known as tropical soybean with high nutritional content. Lack of information on the variance components and heritability of winged bean breeding is one of the reasons for the lack of winged bean breeding programs in Indonesia. This reseach aimed to obtain information on variance components, heritability and relationship between winged bean traits. The experiment was conducted in three environments, from January 2019 to June 2020. Two environments located in Bogor and one in Palembang. Eleven genotypes of winged bean were tested and 11 traits were observed. The result showed that flowering time and seed number per pod performed wide genetic variability. High heritability was observed on seed number per pod (89.48\%), flowering time (83.32\%), young pods length (70.97\%), and weight of 100 seeds $(68.63 \%)$. The results of correlation analysis and path analysis showed that young pod productivity (1.07), seed weight per plot (0.81), flowering time (0.29), young pod length (0.17), young pod width (0.12), seed weight per plant (0.09), and 100 seeds weight (0.01) had a positive direct effect on wing bean productivity. Flowering time, seed number per pod, seed weight per plant are suitable characters for selection criteria for breeding high productivity winged bean.
\end{abstract}

Keywords: correlation, genetic variability, path analysis

\section{ABSTRAK}

Kecipir (Psophocarpus tetragonolobus (L.) DC) dijuluki sebagai kedelai daerah tropis dengan potensi kandungan gizi tinggi. Kurangnya informasi mengenai komponen keragaman dan heritabilitas dalam pemuliaan kecipir menjadi salah satu penyebab belum berkembangnya program pemuliaan kecipir di Indonesia. Penelitian ini bertujuan untuk memperoleh informasi ragam, heritabilitas dan hubungan antar karakter kecipir. Penelitian dilakukan di tiga lingkungan yaitu dua lingkungan di Bogor, dan satu lingkungan di Palembang, pada bulan Januari 2019 sampai dengan Juni 2020. Pengujian dilakukan terhadap 11 genotipe kecipir dan 11 karakter pengamatan. Hasil menunjukkan karakter umur berbunga dan jumlah biji per polong memiliki keragaman genetik yang luas. Nilai heritabilitas tinggi ditunjukkan oleh karakter jumlah biji per polong (89.48\%), umur berbunga (83.32\%), panjang polong muda (70.97\%) dan bobot 100 biji (68.63\%). Hasil analisis lintas menunjukkan karakter produktivitas polong muda (1.07), bobot biji per plot (0.81), umur berbunga (0.29), panjang polong muda (0.17), lebar polong muda (0.12), bobot biji per tanaman (0.09), dan bobot 100 biji (0.01) memiliki pengaruh langsung positif terhadap produktivitas biji kecipir. Umur berbunga, jumlah biji per polong dan bobot biji per tanaman merupakan karakter yang tepat menjadi kriteria seleksi dalam merakit kecipir berproduksi tinggi.

Kata kunci: analisis lintas, keragaman genetik, korelasi

\section{PENDAHULUAN}

Kecipir (Psophocarpus tetragonolobus (L.) DC.) merupakan tanaman kacang-kacangan yang dapat dijumpai

\footnotetext{
* Penulis untuk korespondensi. e-mail: muhsyukur@apps.ipb. ac.id
}

di negara-negara tropis yang lembab dan panas seperti India, Thailand, dan Indonesia (Mohanty et al., 2013). Kecipir merupakan salah satu tanaman yang sangat potensial untuk dikembangkan karena seluruh bagiannya dapat dikonsumsi (Alalade et al., 2016: Leptcha et al., 2017; Tanzi et al., 2019; Mohanty et al., 2020). Tanaman ini juga dapat menjadi pendamping bahkan pengganti kedelai dalam memenuhi kebutuhan nasional, karena kandungan protein kecipir mirip 
dengan kedelai (Amoo et al., 2011; Ningombam et al., 2012; Handayani, 2013). Produktivitas kecipir mencapai 4.5 ton ha $^{-1}$ biji kering dan kedelai memiliki potensi hasil hingga 3,12 ton ha ${ }^{-1}$ biji kering (Hastini et al., 2015 dan Cheriere et al., 2020). Selain biji, polong muda kecipir juga dapat dimanfaatkan sebagai sayuran.

Sebagian besarkecipiryang dikembangkan di Indonesia adalah merupakan landrace lokal. Kecipir lokal yang dibudidayakan petani umumnya memiliki umur dalam yang membutuhkan waktu lebih dari 100 hari untuk munculnya bunga pertama (Eagleton, 2019), sehingga komoditas ini tidak menjadi pilihan utama budidaya dibanding kedelai. Salah satu upaya perbaikan kecipir adalah melalui pemuliaan tanaman untuk menghasilkan varietas yang berumur genjah dan berdaya hasil tinggi (Syukur et al., 2012).

Informasi keragaman genetik perlu diketahui sebelum menentukan metode pemuliaan dalam suatu program pemuliaan tanaman (Syukur et al., 2012). Tingkat keberhasilan suatu seleksi sangat ditentukan oleh keragaman genetik (Sleper dan Poehlman, 2006). Selain itu, nilai heritabilitas juga perlu diketahui untuk menentukan karakter-karakter yang ingin dijadikan target seleksi (Pinaria et al., 1995). Heritabilitas merupakan suatu tolok ukur tingkat keterwarisan suatu karakter dalam populasi tanaman (Sleper dan Poehlman, 2006). Menurut Ardi et al. (2017), nilai ragam genetik karakter kuantitatif kecipir lokal tergolong rendah dan heritabilitasnya bervariasi dari rendah hingga tinggi.

Selain nilai ragam dan nilai duga heritabilitas, pemulia juga perlu mengetahui hubungan antara komponen hasil dan pengaruhnya terhadap daya hasil (Thangamani dan Jansirani, 2012). Analisis korelasi dapat memberikan informasi mengenai derajat hubungan antar karakter penting tanaman untuk membantu memprediksi respon daya hasil (Shekar et al., 2013). Analisis lintas (path analysis) dapat memisahkan efek langsung dan efek tidak langsung dengan membagi koefisien korelasi genotipe (Thangamani dan Jansirani, 2012). Informasi mengenai korelasi dan sidik lintas karakter kecipir masih terbatas sehingga perlu dilakukan penelitian lebih lanjut. Penelitian ini bertujuan untuk memperoleh informasi nilai ragam genetik, heritabilitas dan korelasi antar karakter-karakter penting tanaman kecipir di tiga lingkungan.

\section{BAHAN DAN METODE}

Penelitian dilaksanakan dari bulan Januari 2019 sampai dengan bulan Juni 2020. Penelitian dilaksanakan di tiga lingkungan yaitu Kabupaten Bogor (2 lingkungan) dan Kota Palembang (1 lingkungan).

Penelitian dilakukan dengan menggunakan rancangan kelompok lengkap teracak faktor tunggal yaitu genotipe kecipir dengan tiga ulangan pada setiap lingkungan. Sebelas genotipe kecipir yang diuji pada penelitian ini, ini terdiri atas 2 genotipe tetua dan 9 genotipe hasil persilangan diantara keduanya. Genotipe tetua $1\left(\mathrm{P}_{1}\right)$ yaitu genotipe introduksi dari Thailand, sedangkan genotipe tetua $2\left(\mathrm{P}_{2}\right)$ merupakan genotipe lokal dari Cilacap. Genotipe hasil persilangan yang digunakan merupakan tanaman generasi ke- $7\left(\mathrm{~F}_{7}\right)$ yang terdiri atas $\mathrm{F}_{7}-\mathrm{UxH}-4-1-\mathrm{L} 1-1-1(\mathrm{~B})-\mathrm{B}, \mathrm{F}_{7}-\mathrm{UxH}-4-1-\mathrm{L} 2-1-1(\mathrm{~B})-\mathrm{B}$, $\mathrm{F}_{7}$-UxH-4-1-L3-1-1(B)-B, $\mathrm{F}_{7}$-UxH-4-1-L4-1-1(B)-B, $\mathrm{F}_{7}-$ UxH-4-1-H1(P)-1-1(B)-B, $\quad \mathrm{F}_{7}$-UxH-4-1-H1(U)-1-1(B)-B, $\mathrm{F}_{7}-\mathrm{UxH}-4-1-\mathrm{H} 2-1-1(\mathrm{~B})-\mathrm{B}, \quad \mathrm{F}_{7}-\mathrm{UxH}-4-1-\mathrm{H} 3(\mathrm{U})-1-1(\mathrm{~B})-\mathrm{B}$, dan $\mathrm{F}_{7}-\mathrm{UxH}-4-1-\mathrm{H} 4(\mathrm{P})-1-1(\mathrm{~B})-\mathrm{B}$.

Budidaya diawali dengan pengolahan tanah sebelum penanaman. Luas petakan yang digunakan adalah $5 \mathrm{~m}$ x $1 \mathrm{~m}$ dengan masing-masing genotipe diulang sebanyak tiga kali. Jarak tanam yang digunakan adalah $50 \mathrm{~cm} \times 30 \mathrm{~cm}$ dengan jumlah 28 lubang tanam pada setiap petak. Pemupukan dilakukan dua kali yaitu pada saat tanam dengan dosis urea $50 \mathrm{~kg} \mathrm{ha}^{-1}$, TSP $75 \mathrm{~kg} \mathrm{ha}^{-1}$, dan $\mathrm{KCl} 150 \mathrm{~kg} \mathrm{ha}^{-1}$, pemupukan kedua dilakukan pada saat tiga minggu setelah tanam hanya dengan urea dan TSP pada dosis yang sama. Pemasangan ajir dilakukan di setiap tanaman pada umur 20-30 hari setelah tanam. Pemanenan dilakukan saat polong sudah mengering sempurna dan berwarna cokelat kehitaman.

Peubah yang diamati merujuk pada IBPGR (1978) dan Kementan (2014) yaitu umur berbunga, panjang polong muda, lebar polong muda, bobot polong muda, jumlah biji per polong, bobot biji pertanaman, bobot 100 biji, bobot biji per plot, bobot polong muda per plot, produktivitas polong muda, dan produktivitas biji. Analisis ragam gabungan untuk tiga lingkungan mengacu pada model acak (Tabel 1) (Syukur et al., 2015).

Analisis ragam gabungan dan uji lanjut dilakukan menggunakan perangkat lunak SAS 9.1 dan R. Pendugaan parameter genetik yaitu pendugaan ragam genetik $\left(\sigma_{\mathrm{g}}^{2}\right)$, ragam interaksi genetik x lingkungan $\left(\sigma^{2}{ }_{\text {ge }}\right)$, dan ragam fenotipik $\left(\sigma_{\mathrm{p}}^{2}\right)$ (Hallauer et al., 2010). Nilai estimasi ragam diperoleh dari analisis ragam gabungan melalui rumus berikut : $\sigma_{\mathrm{g}}^{2}=(\mathrm{M} 3-\mathrm{M} 2) / \mathrm{rl}, \sigma_{\mathrm{ge}}^{2}=(\mathrm{M} 2-\mathrm{M} 1) / \mathrm{r}, \sigma_{\mathrm{p}}^{2}=\sigma_{\mathrm{g}}^{2}$ $+\sigma_{\mathrm{ge}}^{2} / 1+\sigma_{\mathrm{e}}^{2} / \mathrm{rl}($ Tabel 1$)$.

Nilai duga heritabilitas dalam arti luas (Syukur et al., 2015) adalah $\mathrm{h}^{2}{ }_{\mathrm{bs}}=\left(\sigma_{\mathrm{g}}^{2} / \sigma_{\mathrm{p}}^{2}\right) \times 100 \%$. Nilai heritabilitas digolongkan sebagai berikut (Stanfield, 1983): rendah $=\mathrm{h}^{2}$ $<20 \%$, sedang $=20 \% \leq \mathrm{h}_{\text {bs }}^{2}<50 \%$, tinggi $=\mathrm{h}_{\text {bs }}^{2} \geq 50 \%$.

Hubungan antar karakter yang diamati dapat diketahui menggunakan analisis korelasi Pearson dan analisis lintas. Hubungan linear antara peubah X (komponen hasil) dan $\mathrm{Y}$ (produktivitas biji) dihitung dengan korelasi Pearson sebagai berikut:

$$
r_{x y}=\frac{\sum\left(x_{i}-\bar{x}\right)\left(y_{i}-\bar{y}\right)}{\sqrt{\left(x_{i}-\bar{x}\right)^{2}} \cdot \sqrt{\left(y_{i}-\bar{y}\right)^{2}}}
$$

Analisis lintas digunakan untuk mengetahui kontribusi suatu karakter bebas terhadap karakter respon apakah berpengaruh langsung atau tidak langsung (Singh dan Chaudhary, 1979).

$$
\begin{aligned}
& {\left[\begin{array}{lll}
r_{11} r_{12} & \ldots \ldots & r_{1 p} \\
r_{21} r_{22} & \ldots \ldots & r_{2 p} \\
r_{p 1} r_{p 2} & \ldots \ldots & r_{p p}
\end{array}\right]\left[\begin{array}{l}
C_{1} \\
C_{2} \\
C_{3}
\end{array}\right]=\left[\begin{array}{l}
r_{1 y} \\
r_{2 y} \\
r_{p y}
\end{array}\right]} \\
& R_{x} \quad \underline{C} \quad R_{y} \\
& \text { Dimana } \underline{C}=R_{x}{ }^{-1} R_{y}
\end{aligned}
$$


Tabel 1. Sidik ragam gabungan model acak

\begin{tabular}{|c|c|c|c|c|}
\hline Sumber keragaman & $\mathrm{db}$ & Kuadrat tengah (KT) & Nilai harapan KT & Uji F \\
\hline Lingkungan (L) & $(1-1)$ & M5 & & M5/M4 \\
\hline Ulangan/Lingkungan & $1(\mathrm{r}-1)$ & M4 & & \\
\hline Genotipe $(\mathrm{G})$ & $(g-1)$ & M3 & $\sigma_{\mathrm{e}}^{2}+r \sigma_{\mathrm{ge}}^{2}+\mathrm{rl} \sigma_{\mathrm{g}}^{2}$ & $\mathrm{M} 3 / \mathrm{M} 2$ \\
\hline GxL & $(g-1)(1-1)$ & M2 & $\sigma_{\mathrm{e}}^{2}+r \sigma_{\mathrm{ge}}^{2}$ & $\mathrm{M} 2 / \mathrm{M} 1$ \\
\hline Galat & $1(\mathrm{~g}-1)(\mathrm{r}-1)$ & M1 & $\sigma_{\mathrm{e}}^{2}$ & \\
\hline
\end{tabular}

Keterangan: 1 = lingkungan; $r=$ ulangan; $g$ = genotipe

Keterangan:

$\mathrm{R}_{\mathrm{x}}=$ matriks korelasi antar peubah bebas; $\mathrm{R}_{\mathrm{x}}^{-1}=$ invers matriks $\mathrm{R}_{\mathrm{x}} ; \mathrm{C}=$ vektor koefisien lintas yang menunjukkan pengaruh langsung setiap peubah bebas terhadap peubah tak bebas; $\mathrm{R}_{\mathrm{y}}=$ vektor koefisien korelasi antara peubah bebas $\mathrm{X}_{\mathrm{i}}$ $(\mathrm{i}=1,2, \ldots, \mathrm{p})$ dengan peubah tak bebas $\mathrm{Y}$.

\section{HASIL DAN PEMBAHASAN}

Hasil analisis ragam gabungan memperlihatkan bahwa lingkungan berpengaruh sangat nyata terhadap seluruh karakter kecuali bobot biji per plot (Tabel 2). Genotipe berpengaruh nyata terhadap karakter bobot biji per tanaman, bobot 100 biji dan berpengaruh sangat nyata terhadap karakter umur berbunga, panjang polong muda, dan jumlah biji per polong. Seluruh karakter yang diamati menunjukkan pengaruh yang sangat nyata pada interaksi genotipe dan lingkungan. Hasil ini menunjukkan bahwa interaksi genotipe dan lingkungan memiliki peran lebih terhadap daya hasil daripada lingkungan dan genetik (Tabel 2).

Karakter umur berbunga dan jumlah biji per polong memiliki keragaman genetik yang luas (Tabel 3). Kedua karakter tersebut efektif dijadikan kriteria seleksi pada suatu populasi. Hasil yang sama dilaporkan oleh Ardi et al. (2017) bahwa karakter umur berbunga dan jumlah biji per polong tanaman kecipir memiliki keragaman genetik yang luas. Sementara itu karakter bobot polong muda, panjang polong muda, lebar polong muda, bobot biji per tanaman, bobot 100 biji, bobot polong muda per plot, produktivitas polong muda, bobot biji per plot, dan produktivitas biji mempunyai keragaman genetik yang sempit, sehingga karakter-karakter tersebut tidak efektif untuk dijadikan kriteria seleksi pada populasi ini. Hermanto et al. (2017) menyebutkan hibridisasi dengan menggunakan populasi yang memiliki hubungan genetik berbeda dengan populasi uji merupakan cara untuk meningkatkan keragaman genetik.

Nilai duga heritabilitas suatu karakter perlu diketahui untuk menduga kemajuan seleksi dan juga mengetahui bahwa suatu karakter tersebut lebih dipengaruhi oleh faktor genetik atau lingkungan (Lestari et al., 2015). Nilai duga heritabilitas ini bermanfaat dalam melakukan proses seleksi (Syukur et al., 2012). Seleksi akan efektif jika populasi memiliki nilai heritabilitas yang tinggi. Karakter yang banyak dipengaruhi oleh lingkungan biasanya memiliki nilai heritabilitas yang tinggi (Jalata et al., 2011). Hal ini akan mempengaruhi prosedur seleksi yang akan digunakan untuk mengembangkan karakter target.

Tabel 2. Kuadrat tengah analisis ragam gabungan karakter kuantitatif 11 genotipe kecipir pada tiga lingkungan

\begin{tabular}{|c|c|c|c|}
\hline \multirow{2}{*}{ Karakter } & \multicolumn{3}{|c|}{ Kuadrat tengah } \\
\hline & Lingkungan (L) & Genotipe (G) & $\mathrm{G} \times \mathrm{L}$ \\
\hline Umur berbunga & $6,973.12 * *$ & $4,563.30^{* *}$ & $761.09 * *$ \\
\hline Bobot polong muda & $289.53 * *$ & $10.55 \mathrm{~ns}$ & $7.15^{* *}$ \\
\hline Panjang polong muda & $72.80 * *$ & $13.53 * *$ & $3.93 * *$ \\
\hline Lebar polong muda & $3.27 * *$ & $0.02 \mathrm{~ns}$ & $0.02 *$ \\
\hline Jumlah biji per polong & $18.38^{* *}$ & $21.41 * *$ & $2.25^{*}$ \\
\hline Bobot biji per tanaman & $9,030.53 * *$ & $918.33^{*}$ & $766.86 * *$ \\
\hline Bobot 100 biji & $141.64 * *$ & $51.18^{*}$ & $18.59 * *$ \\
\hline Bobot polong muda per plot & $33,423,202.00 * *$ & $95,9721.00 \mathrm{~ns}$ & $707,017.00 * *$ \\
\hline Produktivitas polong muda & $269.95 * *$ & $6.79 \mathrm{~ns}$ & $3.80 * *$ \\
\hline Bobot biji per plot & $1,370,375.00 *$ & $276,280.00 \mathrm{~ns}$ & $168,613.00^{* *}$ \\
\hline Produktivitas biji & $17.53 * *$ & $1.82 \mathrm{~ns}$ & $1.36^{* *}$ \\
\hline
\end{tabular}

Keterangan: $*$ berpengaruh nyata pada $\alpha=5 \%$;* $=$ berpengaruh nyata pada $\alpha=1 \%$; ns $=$ tidak berpengaruh nyata 
Tabel 3. Nilai koefisien keragaman genetik, ragam genetik dan standar deviasi ragam genetik beberapa karakter 11 genotipe kecipir

\begin{tabular}{lcrcl}
\hline Karakter & KKG $(\%)$ & \multicolumn{1}{c}{$\sigma_{\mathrm{g}}^{2}$} & $\sigma\left(\sigma_{\mathrm{g}}^{2}\right)$ & Kriteria \\
\hline Umur berbunga & 25.29 & 422.47 & 208.56 & Luas \\
Bobot polong muda & 5.32 & 0.38 & 0.54 & Sempit \\
Panjang polong muda & 6.01 & 1.07 & 0.63 & Sempit \\
Lebar polong muda & 0.73 & 0.000 & 0.00 & Sempit \\
Jumlah biji per polong & 11.76 & 2.13 & 0.97 & Luas \\
Bobot biji per tanaman & 9.23 & 16.83 & 48.94 & Sempit \\
Bobot 100 biji & 5.15 & 3.62 & 2.40 & Sempit \\
Bobot polong muda per plot & 11.54 & 28078 & $49,560.24$ & Sempit \\
Produktivitas polong muda & 12.24 & 0.33 & 0.33 & Sempit \\
Bobot biji per plot & 14.35 & 11963 & $13,746.56$ & Sempit \\
Produktivitas biji & 9.93 & 0.05 & 0.09 & Sempit \\
\hline
\end{tabular}

Keterangan: $\mathrm{KKG}=$ Koefisien keragaman genetik; $\sigma_{\mathrm{g}}^{2}=$ ragam genetik; $\sigma\left(\sigma_{\mathrm{g}}^{2}\right)=$ standar deviasi ragam genetik

Selain itu pendugaan ragam genetik, interaksi genetik $\mathrm{x}$ lingkungan dan heritabilitas (Tabel 4) akan lebih baik pada percobaan beberapa lingkungan dibanding hanya pada satu lingkungan.

Karakter umur berbunga, panjang polong muda, jumlah biji per polong dan bobot 100 biji memiliki nilai duga heritabilitas yang tinggi (Tabel 4). Hasil penelitian Ardi et al. (2017) menunjukkan hal yang serupa yaitu keempat karakter tersebut memiliki nilai duga heritabilitas yang tinggi. Nilai heritabilitas arti luas yang tinggi pada suatu karakter mengindikasikan karakter tersebut memiliki nilai pemuliaan (breeding value) tinggi yang dipengaruhi oleh adanya gen aditif (Udensi et al., 2012). Perbaikan karakter yang memiliki nilai heritabilitas tinggi lebih mudah dibandingkan karakter dengan heritabilitas rendah (Sujiprihati et al., 2003). Karakter bobot polong muda, bobot polong muda per plot, bobot biji per plot, produktivitas polong muda dan produktivitas biji mempunyai nilai duga heritabilitas sedang. Prasanth dan Sreelatha (2014) melaporkan hal yang sama terjadi pada karakter bobot polong muda dan bobot polong per plot.

Produktivitas biji merupakan komponen utama dari setiap tanaman legume karena bernilai ekonomis. Hasil biji merupakan sifat yang diwariskan secara kuantitatif dan dikendalikan oleh banyak gen. Penentuan karakter-karakter yang memiliki kaitan dengan karakter hasil memerlukan informasi hubungan antara setiap karakater. Hubungan antar karakter dapat diketahui dengan menggunakan analisis korelasi. Nilai koefisien korelasi menjadi tolok ukur tingkat keeratan hubungan antar karakter.

Hasil analisis korelasi antar karakter disajikan pada Tabel 5. Hasil uji menunjukkan bahwa karakter komponen

Tabel 4. Ragam genotipe, ragam interaksi genetik x lingkungan, ragam galat, ragam fenotip, heritabilitas dan standar deviasi heritabilitas beberapa karakter 11 genotipe kecipir pada tiga lingkungan

\begin{tabular}{|c|c|c|c|c|c|c|c|}
\hline & $\sigma_{g}^{2}$ & $\sigma_{\mathrm{ge}}^{2}$ & $\sigma_{\mathrm{e}}^{2}$ & $\sigma_{p}^{2}$ & $\mathrm{~h}_{\mathrm{bs}}^{2}(\%)$ & $\sigma\left(h^{2}\right)$ & Kriteria $h^{2}{ }_{b s}$ \\
\hline Umur berbunga & 422.47 & 247.99 & 17.11 & 507.03 & 83.32 & 0.79 & Tinggi \\
\hline Bobot polong muda & 0.38 & 2.13 & 0.75 & 1.17 & 32.20 & 0.19 & Sedang \\
\hline Panjang polong muda & 1.07 & 1.11 & 0.59 & 1.50 & 70.97 & 0.37 & Tinggi \\
\hline Lebar polong muda & 0.000 & 0.003 & 0.01 & 0.002 & 13.72 & 0.08 & Rendah \\
\hline Jumlah biji per polong & 2.13 & 0.32 & 1.29 & 2.38 & 89.48 & 0.60 & Tinggi \\
\hline Bobot biji per tanaman & 16.83 & 200.56 & 165.18 & 102.04 & 16.49 & 0.13 & Rendah \\
\hline Bobot 100 biji & 3.62 & 5.14 & 3.17 & 5.69 & 63.68 & 0.29 & Tinggi \\
\hline Bobot polong muda per plot & $28,078.00$ & $19,1170.00$ & $133,506.00$ & $106,635.33$ & 26.33 & 0.15 & Sedang \\
\hline Produktivitas polong muda & 0.33 & 0.96 & 0.91 & 0.75 & 44.05 & 0.18 & Sedang \\
\hline Bobot biji per plot & $11,963.00$ & 44125 & 36239 & $30,697.89$ & 38.97 & 0.17 & Sedang \\
\hline Produktivitas biji & 0.05 & 0.35 & 0.31 & 0.20 & 25.52 & 0.14 & Sedang \\
\hline
\end{tabular}

Keterangan: $\sigma_{\mathrm{g}}^{2}=$ ragam genetik; $\sigma_{\text {ge }}^{2}=$ ragam interaksi genetik x lingkungan; $\sigma_{\mathrm{e}}^{2}=$ ragam galat; $\sigma_{\mathrm{p}}^{2}:$ ragam fenotip; ${ }^{2}{ }_{\mathrm{bs}}=$ heritabilitas dan $\sigma\left(\mathrm{h}^{2}\right)=$ standar deviasi heritabilitas 
Tabel 5. Nilai koefisien korelasi Pearson beberapa karakter dari 11 genotipe kecipir pada tiga lingkungan

\begin{tabular}{|c|c|c|c|c|c|c|c|c|c|c|c|}
\hline & UB & BBPM & PJPM & LBPM & JMBP & BBTN & B100 & BPMP & PRPM & BBPL & PRB \\
\hline UB & 1 & $0.69 *$ & $0.43 \mathrm{tn}$ & $0.5 \mathrm{tn}$ & $-0.21 \mathrm{tn}$ & $-0.8 * *$ & $-0.44 \operatorname{tn}$ & $-0.88 * *$ & $-0.89 * *$ & $-0.89 * *$ & $-0.85 * *$ \\
\hline BBPM & & 1 & $0.88 * *$ & $0.77 * *$ & $0.47 \mathrm{tn}$ & $-0.35 \mathrm{tn}$ & $0.02 \mathrm{tn}$ & $-0.76 * *$ & $-0.67 *$ & $-0.71 * *$ & $-0.67 *$ \\
\hline PJPM & & & 1 & $0.75 * *$ & $0.74 * *$ & $-0.10 \mathrm{tn}$ & $0.39 \mathrm{tn}$ & $-0.66^{*}$ & $-0.55 \mathrm{tn}$ & $-0.55 \mathrm{tn}$ & $-0.52 \mathrm{tn}$ \\
\hline LBPM & & & & 1 & $0.47 \mathrm{tn}$ & $-0.42 \mathrm{tn}$ & $0.25 \mathrm{tn}$ & $-0.70^{*}$ & $-0.71 * *$ & $-0.70^{*}$ & $-0.74 * *$ \\
\hline JMBP & & & & & 1 & $0.44 \mathrm{tn}$ & $0.63 *$ & $-0.05 \mathrm{tn}$ & $0.07 \mathrm{tn}$ & $0.06 \mathrm{tn}$ & $0.06 \mathrm{tn}$ \\
\hline BBTN & & & & & & 1 & $0.43 \mathrm{tn}$ & $0.72 * *$ & $0.78 * *$ & $0.82 * *$ & $0.81 * *$ \\
\hline B100 & & & & & & & 1 & $-0.03 \mathrm{tn}$ & $0.09 \mathrm{tn}$ & $0.12 \mathrm{tn}$ & $0.14 \mathrm{tn}$ \\
\hline BPMP & & & & & & & & 1 & $0.96 * *$ & $0.96 * *$ & $0.91 * *$ \\
\hline PRPM & & & & & & & & & 1 & $0.97 * *$ & $0.97 * *$ \\
\hline BBPL & & & & & & & & & & 1 & $0.98 * *$ \\
\hline PRB & & & & & & & & & & & 1 \\
\hline
\end{tabular}

Keterangan: $*$ = berkorelasi nyata pada $\alpha=5 \% ; * *=$ berkorelasi nyata pada taraf $\alpha=1 \%$; tn = tidak berpengaruh nyata; UB = Umur berbunga; BBPM = Bobot polong muda; PJPM = Panjang polong muda; LBPM = Lebar polong muda; JMBP = Jumlah biji per polong; $\mathrm{BBTN}=$ Bobot biji per tanaman; $\mathrm{B} 100=$ Bobot 100 biji; $\mathrm{BPMP}=$ Bobot polong muda per plot; $\mathrm{PRPM}=$ Produktivitas polong muda per ha; $\mathrm{BBPL}=$ Bobot biji per plot; $\mathrm{PRB}=$ Produktivitas biji per ha

hasil seperti bobot biji per plot $(\mathrm{r}=0.98)$, produktivitas polong muda $(\mathrm{r}=0.97)$, bobot polong muda per plot $(\mathrm{r}$ $=0.91)$, dan bobot biji per tanaman $(\mathrm{r}=0.81)$ memiliki korelasi positif yang nyata terhadap produktivitas biji. Seleksi massal terhadap karakter kompenen hasil tersebut dapat menimbulkan peningkatan daya hasil karena saling berkorelasi positif (Putri et al., 2017). Karakter umur berbunga, bobot polong muda, dan lebar polong muda berkorelasi negatif nyata terhadap produktivitas biji.

Hubungan antara satu karakter dengan karakter lain dapat diidentifikasi melalui analisis lintas. Analisis ini mampu menyajikan pengaruh langsung, pengaruh tidak langsung antar karakter maupun pengaruh total (Hefny, 2011). Pengaruh langsung adalah karakter yang memiliki pengaruh terhadap daya hasil tanpa melalui karakter lain. Pengaruh tidak langsung adalah pengaruh suatu karakter terhadap karkater hasil melalui karakter lain, sedangkan pengaruh total adalah jumlah gabungan nilai pengaruh langsung maupun tidak langsung suatu karakter (Bondari, 1990).

Analisis sidik lintas dapat menyajikan informasi mengenaibagaimanakarakterkomponenhasilmempengaruhi

Tabel 6. Nilai pengaruh langsung dan tidak langsung karakter komponen hasil dan karakter agronomis terhadap produktivitas biji kecipir

\begin{tabular}{|c|c|c|c|c|c|c|c|c|c|c|c|c|}
\hline \multirow{2}{*}{$\mathrm{X}$} & \multirow{2}{*}{$\begin{array}{l}\text { Pengaruh } \\
\text { langsung }\end{array}$} & \multicolumn{10}{|c|}{ Pengaruh tak langsung } & \multirow{2}{*}{ rXY } \\
\hline & & UB & BBPM & PJPM & LBPM & JMBP & BBTN & B100 & BPMP & PRPM & BBPL & \\
\hline UB & 0.296 & & -0.191 & 0.075 & 0.061 & 0.030 & -0.078 & -0.005 & 0.638 & -0.956 & -0.721 & -0.851 \\
\hline BBPM & -0.276 & 0.204 & & 0.153 & 0.094 & -0.068 & -0.034 & 0.001 & 0.551 & -0.720 & -0.575 & -0.670 \\
\hline PJPM & 0.174 & 0.127 & -0.243 & & 0.092 & -0.107 & -0.010 & 0.004 & 0.479 & -0.591 & -0.445 & -0.520 \\
\hline LBPM & 0.123 & 0.148 & -0.213 & 0.131 & & -0.068 & -0.041 & 0.003 & 0.508 & -0.763 & -0.567 & -0.739 \\
\hline JMBP & -0.144 & -0.062 & -0.130 & 0.129 & 0.058 & & & 0.006 & 0.036 & 0.075 & 0.049 & 0.060 \\
\hline BBTN & 0.098 & -0.237 & 0.097 & -0.017 & -0.052 & -0.063 & & 0.004 & -0.522 & 0.838 & 0.664 & 0.810 \\
\hline B100 & & -0.130 & -0.006 & 0.068 & 0.031 & -0.091 & 0.042 & & 0.022 & 0.097 & 0.097 & 0.140 \\
\hline BPMP & -0.725 & -0.261 & 0.210 & -0.115 & -0.086 & 0.007 & 0.070 & -0.001 & & 1.032 & 0.777 & 0.908 \\
\hline PRPM & 1.075 & -0.264 & 0.185 & -0.096 & -0.087 & -0.010 & 0.076 & 0.001 & -0.696 & & 0.786 & 0.970 \\
\hline BBPL & 0.810 & -0.264 & 0.196 & -0.096 & -0.086 & -0.009 & 0.080 & 0.001 & -0.696 & 1.042 & & 0.978 \\
\hline
\end{tabular}

Sisa $=-0.0004$

Keterangan: $\mathrm{UB}=$ Umur berbunga; $\mathrm{BBPM}=$ Bobot polong muda; PJPM = Panjang polong muda; LBPM = Lebar polong muda; JMBP = Jumlah biji per polong; BBTN = Bobot biji per tanaman; B100 = Bobot 100 biji; BPMP = Bobot polong muda per plot; PRPM = Produktivitas polong muda per ha; $\mathrm{BBPL}=$ Bobot biji per plot; $\mathrm{PRB}=$ Produktivitas biji per ha; $r X Y=$ Koefisien korelasi peubah dengan produktivitas biji 
produktivitas biji. Dalam kegiatan memperbaiki daya hasil, hasil analisis ini dapat menjadi gambaran keefektifan dalam seleksi suatu karakter. Hasil analisis lintas disajikan pada Tabel 6. Karakter yang memiliki pengaruh langsung positif terhadap produktivitas biji adalah produktivitas polong muda (1.075), bobot biji per plot (0.810), umur berbunga (0.296), panjang polong muda (0.174), lebar polong muda (0.123), bobot biji per tanaman (0.098) dan bobot 100 biji (0.010). Karekter yang memiliki nilai pengaruh langsung terbesar terhadap produktivitas biji adalah produktivitas polong muda (1.075) dan bobot biji per plot (0.810). Nilai pengaruh langsung yang lebih besar dari 1 ini diduga akibat adanya dua atau lebih variabel bebas yang memiliki korelasi tinggi (Putri et al., 2017). Karakter bobot polong muda dan bobot biji pertanaman memiliki pengaruh tidak langsung terhadap produktivitas biji melalui karakter produktivitas polong muda. Karakter jumlah biji per polong dan bobot 100 biji memiliki pengaruh tidak langsung yang kecil terhadap produktivitas biji melalui karakter bobot biji per plot. Pengaruh karakter lain yang tidak bisa dijelaskan oleh model dan yang tidak dimasukkan ke dalam analisis merupakan nilai sisa (Nasution, 2010).

\section{KESIMPULAN}

Karakter umur berbunga dan jumlah biji per polong memiliki nilai keragaman genetik yang luas. Karakter yang memiliki nilai heritabilitas tinggi adalah karakter umur berbunga, panjang polong, jumlah biji per polong dan bobot 100 biji. Hasil analisis korelasi dan analisis lintas menunjukkan karakter umur berbunga, panjang polong, lebar polong, bobot biji pertanaman, bobot 100 biji, bobot biji per plot, produktivitas polong muda memiliki pengaruh langsung positif terhadap produktivitas biji. Umur berbunga, jumlah biji per polong dan bobot biji per tanaman merupakan karakter yang tepat menjadi kriteria seleksi dalam merakit kecipir berproduksi tinggi.

\section{UCAPAN TERIMA KASIH}

Terima kasih disampaikan kepada Kemenristek/BRIN yang telah membiayai penelitian ini melalui Hibah Penelitian Terapan Tahun 2019 dan 2020 a.n. Muhamad Syukur.

\section{DAFTAR PUSTAKA}

Alalade, J., J. Akinlade, O. Aderinola, A. Fajemisin, T. Muraina, T. Amoo. 2016. Proximate, mineral, and anti-nutrientcontents in Psophocarpustetragonolobus (L.) DC. (winged bean) leaves. Brit. J. Pharm. Res. 10:1-7. Doi:10.9734/bjpr/2016/22087.

Bondari, K. 1990. Path analysis in agricultural research. p. 133-145. In G. A Milliken, J. R. Schwenke (Eds.) Proceedings of the 1990 Kansas State University
Conference on Applied Statistics in Agriculture. Manhattan, KS. USA. April 29 - May 1, 1990. Doi: $10.4148 / 2475-7772.1439$

Amoo, I., O. Adebayo., A. Oyeleye. 2011. Chemical evaluation of winged beans (Psophocarpus tetragonolobus), Pitanga cherries (Eugenia uniflora) and orchid fruit (Orchid fruit myristica). Afr. J. Food. Agric. Nutr. Dev. 6:1-12. Doi:10.4314/ajfand. v6i2.71734.

Ardi, N.A.P., I. Yulianah., Kusmanto. 2017. Evaluasi karakteristik dan keragaman 16 genotipe tanaman kecipir (Psophocarpus tetragonolobus L.). J. Prod. Tan. 5:1243-1249.

Cheriere, T., M. Lorin, G. Corre-Hellou. 2020. Species choice and spatial arrangement in soybean-based intercropping: Levers that drive yield and weed control. Field Crops Res. 256:107923. Doi:10.1016/ j.fcr.2020.107923.

Eagleton, G.E. 2019. Prospects for developing an early maturing variety of winged bean (psophocarpus tetragonolobus) in Bogor, Indonesia. Biodiversity. 20:3142-3152. Doi:10.13057/biodiv/d201106.

Hallauer,A.R., M.J.Carena., J.B.M. Filho. 2010. Introduction in quantitative genetics in maize breeding. Springer Publ. New York, USA. https://doi.org/10.1007/9781-4419-0766-0_1.

Handayani, T. 2013. Kecipir (Psophocarpus tetragonolobus L.) potensi lokal yang terpinggirkan. J. IPTEK Tanaman Sayuran. 1:1-8. Doi:/10.1067/ mtc.2001.112466.

Hastini, T., S.L. Mulijanti, N. Sunandar. 2015. Potensi hasil enam varietas unggul kedelai di Kabupaten Sumedang. hal. 219-224. Prosiding Seminar Hasil Penelitian Tanaman Aneka Kacang dan Umbi. Malang 15 Mei 2015.

Hefny, M. 2011. Genetic parameters and path analysis of yield and its components in corn inbred lines (Zea mays L.) at different sowing dates. Asian. J. Crop. Sci. 3:106-117. Doi:10.3923/ajcs.2011.106.117.

Hermanto, R., M. Syukur, Widodo. 2017. Pendugaan ragam genetik dan heritabilitas karakter hasil dan komponen hasil tomat (Lycopersicum esculentum Mill.) di dua lokasi. J. Hort. Indonesia 8:31. Doi:10.29244/ jhi.8.1.31-38. 
[IBPGR] International Board for Plant Genetic Resources. 1979. Descriptors for Winged Bean. Regional Committee for Southeast Asia. Food and Agriculture Organization of the United Nation, Rome, Italy.

Jalata, Z., A. Ayana, H. Zeleke. 2011. Variability, heritability and genetic advance for some yield and yield related traits in ethiopian Barley (Hordeum vulgare L.) landraces and crosses. Int. J. Plant Breeding Genet. 5:44-52. Doi:10.3923/ijpbg.2011.44.52.

[Kementan] Kementrian Pertanian Republik Indonesia. 2014. Panduan pelaksanaan uji (PPU) keunikan, keseragaman dan kestabilan kecipir (Psophocarpus tetragonolobus). Pusat Perlindungan Varietas Tanaman dan Perizinan Pertanian, Jakarta, Indonesia.

Lestari, A.D., W. Dewi, W.A. Qosim, M. Rahardja, N. Rostini, R. Setiamihardja. 2015. Variabilitas genetik dan heritabilitas karakter komponen hasil dan hasil lima belas genotip cabai merah. Zuriat. 17:1. Doi:10.24198/zuriat.v17i1.6808.

Mohanty, C.S., S. Verma, V. Singh, P. Khan, P. Gaur, P. Gupta, M.A. Nizar, N. Dikshit, R. Pattanayak, A. Shukla, A. Niranjan, N. Sahu, S.K. Behera, T.S. Rana. 2013. Characterization of winged bean (Psophocarpus tetragonolobus (L.) DC.) based on molecular, chemical and physiological parameters. Amer. J. Mol. Biol. 3:187-197. Doi:10.4236/ajmb.2013.34025.

Mohanty, C.S., V. Singh, M.A. Chapman. 2020. Winged bean: An underutilized tropical legume on the path of improvement, to help mitigate food and nutrition security. Sci. Hortic. 260:108789. Doi:10.1016/ j.scienta.2019.108789.

Nasution, M.A. 2010. Analisis korelasi dan sidik lintas antara karakter morfologi dan komponen buah tanaman nenas (Ananas comosus L. Merr.). Crop Agro. 3:1-9.

Ningombam, R.D., P.K. Singh, J.S. Salam. 2012. Proximate compositionandnutritionalevaluationofunderutilized legume Psophocarpus tetragonolobus (L.) DC. Grown in Manipur, Northeast India. Amer. J. Food Tech. 7:487-493. Doi:10.3923/ajft.2012.487.493.

Pinaria, A., A. Baihaki, R. Setiamihardja, A.A. Daradjat. 1995. Variabilitas genetik dan heritabilitas karakterkarakter biomassa 53 genotipe kedelai. Zuriat 6:8892.

Prasanth, K., K.I. Sreelatha. 2014. Variability and heritability studies for pod yield and its component characters in winged bean [Psophocarpus tetragonolobus (L.) DC.]. The Bioscan. 9:1795-1797.

Putri, F.D., Sobir, M. Syukur, A. Maharijaya. 2017. Pengembangan kriteria seleksi untuk perakitan terung (Solanum melongena L.) berdaya hasil tinggi. J. Agron. Indonesia. 45:182. Doi:10.24831/jai. v45i2.13077.

Shekar, K.C., P. Ashok., K. Sasikala. 2013. Characterization, character association, and path coefficient analyses in eggplant. Int. J. Vegetable. Sci. 19:45-57. Doi:10.1 080/19315260.2012.671803.

Singh, R.K., B.D. Chaudhary. 1979. Biometrical methods in quantitative genetic analysis. Kalyani Publishers, Ludhiana, New Delhi.

Sleper, D.A., J.M. Poehlman. 2006. Breeding field crops. 5th edition. Blackwell Publishing, Ames, Iowa, USA.

Stanfield, W.D. 1983. Theory and problems of genetics. 2nd Ed. McGraw-Hill, New York, USA.

Sujiprihati, S., B.G. Saleh., E.S. Ali. 2003. Heritability, performance and correlation studies on single cross hybrids of tropical maize. Asian J. Plant Sci. 2:51-57. Doi:10.3923/ajps.2003.51.57.

Syukur, M., S. Sujiprihati, R. Yunianti, K. Nida. 2012. Pendugaan komponen ragam, heritabilitas dan korelasi untuk menentukan kriteria seleksi cabai (Capsicum annuum L.) populasi F5. J. Hort. Indonesia 1:74-80. Doi:10.29244/jhi.1.2.74-80.

Syukur, M., S. Sujiprihati, R. Yunianti. 2015. Teknik pemuliaan tanaman edisi revisi. Penebar Swadaya, Jakarta, ID.

Tanzi, A.S., G.E. Eagleton, W.K Ho, Q.N. Wong, S. Mayes, F. Massawe. 2019. Winged bean (Psophocarpus tetragonolobus (L.) DC.) for food and nutritional security: synthesis of past research and future direction. Planta. 250:911-931. Doi:10.1007/s00425019-03141-2.

Thangamani, C., P. Jansirani. 2012. Correllation and path coefficient analysis studies on yield and attributing characters in brinjal (Solanum melongena L.). Electron J. Plant Breeding. 3:939-944.

Udensi, O., E.A. Edu, E.V. Ikpeme, J.K. Ebiwgai, D.E. Ekpe. 2012. Biometrical evaluation and yield performance assessment of cowpea [Vigna unguiculata (L.) Walp] landraces grown under lowland tropical conditions. Int. J. Plant Breeding Genet. 6:47-53. Doi:10.3923/ ijpbg.2012.47.53. 